\title{
GLACIER RETREAT IN JAN MAYEN
}

\author{
By J. N. Jennings (University College, Leicester)
}

\section{INTRODUCTION}

A brief account of the glaciers of Jan Mayen was published as an appendix to A. King's account of the Imperial College of Science Expedition to that island in the summer of 1938.1 $\mathrm{S}$. Thorarinsson has referred to my conclusions on glacier retreat. ${ }^{2}$ Fuller evidence for these conclusions is here given, including a record of the state of the ice margin in 1938 which will thus be available for purposes of comparison in the future. Lack of adequate maps prevents an exact record; those of the Austrian 1882-83 Polar Year Expedition ${ }^{3}$ were found to be inaccurate except in the narrow waist of the island. In the summer of 1938 the bad weather limited our own surveys. W. H. Ward triangulated by theodolite from the waist as far north as the Beerenberg summit and as far east as the South Glacier. He also made a plane table survey of the lower part of the latter glacier on a large scale. Elsewhere it proved possible only to correct certain important errors of the Austrian survey by means of compass observations and by the use of photographs. The accuracy of the accompanying sketch-map of the glaciers of Jan Mayen is therefore of a low order.

\section{The Relief and Nature of the Glaciation}

The Beerenberg forms the north-eastern part of Jan Mayen; on its slopes are found all the glaciers of the island.* This large volcano consists of two cones, superimposed the one on the other. The broad, basal cone rises gradually to heights varying from $4500 \mathrm{ft}$. to $5500 \mathrm{ft}$. ( $1372 \mathrm{~m}$. to $1676 \mathrm{~m}$.) while the inner one rises considerably more steeply to the highest points of the island, including Haakon Peak, $7680 \mathrm{ft}$. $(2340 \mathrm{~m}$.). The basal cone has suffered severely from marine erosion and from Cape Fishburn to Muyen's Cape there are cliffs of interbedded tuffs and lavas ranging from a few hundred feet in height to between 1000 and $2000 \mathrm{ft}$. (approximately $300-$ $600 \mathrm{~m}$.). In front of these cliffs from Clandeboy Cove to East Cross Bay, recent lava flows have built out low extensions of the island. From East Cross Bay to North West Cape the former coast, as represented by the high cliff line, again lies a short distance inland from the present shore. The cause of this shelf, across which the glaciers extend their flat tongues, is not apparent. On the southwest there is a gradual fall in height to the waist of the island where the relief is quite independent of the Beerenberg. Several small volcanoes, such as the Bylandt Rheidt, Sars and Palffy Craters, diversify the lower slopes of the Beerenberg. Their cones are relatively perfect in form and are of recent origin.

The main structure of the mountain seems to be simple since the lavas were seen to be dipping radially outwards from the crater wherever exposed in rock walls. The upper cone preserves the form of the original crater. The horseshoe rim has a length of nearly $2 \frac{1}{2}$ miles $(4 \mathrm{~km}$.), more than half the original circumference. The wide break through the rim on the north, out of which the ice flows to form the Weyprecht Glacier, is probably due to a violent volcanic explosion.

The upper cone is covered with névé and ice except on the steepest faces. The glaciers have eroded the outer slopes to form shallow hollows and cirques separated by ridges, some capped, others entirely covered with ice. Cirque formation has not advanced far, except at the heads of the east-flowing glaciers and Fotherby Glacier. Within the crater, there is evidence of active backward sapping of the rock walls which, together with the incipient cirques on the outer slopes, has given the rim its serrated character. The difierence in the altitude of peaks and cols is greatest near Mercanton Peak where the best developed cirques lie.

\footnotetext{
* See Fig. 1 and illustrations on p. 170-7r.
} 
The trunks of the radially arranged glaciers occupy the basal cone. A middle zone below the upper cone has the most continuous girdle of ice, since some of the glaciers are contiguous at this level but separated above and below, e.g. the South and Fotherby Glaciers, whilst other glaciers branch at low levels. The glaciers of volcanic cones usually diverge and branch instead of uniting and concentrating. ${ }^{4,5}$ At the lower levels, the glaciers occupy wide but usually shallow valleys. The valleys of the lower South and Fotherby Glaciers are so shallow that the glaciers have the appearance of resting on the mountain slopes bounded by moraine ridges. On the other hand, the glaciers running north wards have incised more deeply into the volcanic mass. Amongst these are the Weyprecht, Kjerulf and Swend Foyn Glaciers which are the most active in the island. Some of the smaller volcanoes of Jan Mayen have what Wordie 6 terms a "final runout," namely, a channel in the volcano's side leading downwards from a break in the crater rim. There is the possibility, therefore, that the Weyprecht Glacier may have occupied a volcanic channel of this type. The east-flowing glaciers reaching the coastal cliffs descend in steep and broken icefalls. In certain cases, however, the icefall does not coincide with the cliff line but lies some little way inland. This recession of the step may be due to the sapping observed below the retreating icefall of the Petersen Glacier.

Wordie has pointed out that the Beerenberg must be recent in age since it is relatively perfect in form. The surface forms of lava flows of the ropy or "pahoehoe" type were observed at high levels on the ridges between the South and Fotherby Glaciers and between the Weyprecht and Kjerulf Glaciers. They were not exhumed and, since such features could not long endure the frostshattering of the climate, it suggests that the Beerenberg is not earlier than Pleistocene in age. Glaciers must have occupied its slopes from the start and been mainly responsible for erosion. In the island as a whole there is a striking absence of signs of general glaciation. If this observation is confirmed there arises the question as to whether the island was in the main ice-free in the Pleistocene or whether it is largely of Holocene age.

\section{The State of the Ice Margin in 1938}

Although no signs of former glaciation were observed in the south and central parts of the island, retreat phenomena of some interest were seen close to the ice margin. These will now be described to furnish a basis for future comparison.

The South Glacier. Ward's map ( $\mathrm{I}$ ) on a scale of $\mathrm{I}: 5^{000}$ of the end of the South Glacier, shows clearly the existence of two sets of moraines. Most outstanding are the rampart-like outer lateral moraines, whose height above the glacier surface varies from 120 to $200 \mathrm{ft}$. (37 m. to 6r m.). The eastern moraine stretches inland for $\mathrm{I}_{4}^{1}$ miles $(2 \mathrm{~km}$.) before it merges into low cliffs. The western moraine runs further inland but is broken before reaching a corresponding line of cliffs. The outer faces of these moraines are stable and well colonized by plants; the inner slopes are steeper and looser, yet the slip faces show no signs of enclosed ice. Immediately behind the beach a series of small hillocks, cut by the meltwater streams, link the seaward ends of the outer lateral moraines. They are the final relics of an outer terminal moraine, which must have lain seawards of the present high-water mark. Within this line of glaciated rubble, outwash material extends for 250 to $55^{\circ} \mathrm{yd}$. $(230 \mathrm{~m}$. to $500 \mathrm{~m}$.) to the present terminal moraine. Rock outcrops show this terminal to be quite thin and undisturbed, the ice thinning out towards it. Joining the present terminal are discontinuous laterals. They are very unstable and include much dead ice; they are not vegetated. Their maximum height above the flat glacier surface is no more than $50 \mathrm{ft}$. ( $15 \mathrm{~m}$.).

The Fotherby Glacier. The flat tongue of the Fotherby Glacier projects almost to Cape Hope and here again two sets of moraines can be distinguished. Close to the cliff lies an outer terminal moraine at a distance of $500 \mathrm{yd}$. $(457 \mathrm{~m}$.) from the present terminal moraine. A small lake occupies part of the hollow between the two. Deep meltwater channels separate the outer terminal from its 
laterals. The latter stand well above the glacier surface and partly rest on rock ridges. The inner laterals, rising only $30 \mathrm{ft}$. $(9 \mathrm{~m}$.) above the ice, are quite different, being very unstable, lacking vegetation and including much ice. This twofold arrangement indicates that there has been a considerable and rapid retreat of the glacier snout and an equivalent decrease in the thickness of the ice between the formation of the older and the younger moraines. Certain features - the flatness of the ice tongue, the fact that the inner moraines show no sign of pressure and are already beginning to stand above the ice-suggest that the retreat is still in progress.

The Petersen Glacier now ends about $500 \mathrm{yd}$. $(457 \mathrm{~m}$.) from the sea at an altitude of approximately $600 \mathrm{ft}$. ( $183 \mathrm{~m}$.). Two steep channels, inset into the cliffs and separated by a narrow ridge, link the snout to the sea. These channels show every sign of the recent presence of ice. Moraine, and outwash occupy the less steep parts. Between are a series of "lips"; smoothed and striated surfaces alternate with abrupt "risers" which occasionally overhang. The risers occur mainly along the outcrops of red and buff tuffs, which alternate with the lavas. Certain steps occur entirely within the resistant strata. Smoothed surfaces also extend high up the sides of both channels. The glacier now ends as dirty, flat ice tapering out on a slope too steep for the accumulation of moraine. Some isolated masses of dead ice lie in front of the main body.

The Wille Glacier terminates on the shore in cliffs rising to $30 \mathrm{ft}$. $(9 \mathrm{~m}$.) in height. It descends from above cliff level in a steep and broken icefall. At the snout, the surface and lower layers are heavily laden with moraine. The icefall does not quite fill the valley; dead ice and moraine line its sides. Clean, smoothed rock extends high above the ice on the valley walls. The ice must recently have filled the valley to a considerably greater depth.

The Grieg Glacier also reaches the coast but its cliffs are lower and its ice dirtier. The cliff ice is not joined to the main body of the glacier; the rock floor is widely exposed above the terminal ice cliff. Three hundred feet ( $9 \mathrm{I} \mathrm{m}$.) or more of smoothed side wall is to be seen above the ice tongue, contrasting with the weathered and vegetated slopes higher up.

The Friele Glacier is the most active of the east coast, but it presents two distinct portions to the sea. The southernmost ends in high cliffs, rising to an estimated height of $80 \mathrm{ft}$. $(24 \mathrm{~m}$.). The northern portion has no ice cliff; there are large exposures of smoothed rock, while elsewhere there is a thin cover of black, dead ice. The end of the glacier as a continuous mass lies some distance behind the shore-line.

The Dufferin Glacier now ends more than $500 \mathrm{ft}$. ( $15^{2} \mathrm{~m}$.) up in the cliffs; smoothed channels stretch down to the shore but they are not deeply incised into the cliff. The slope is too steep for the accumulation of any but highly irregular patches of moraine.

The Sigurd Glacier. Here the ice projects further down the cliffs. Its limit lies over a quarter of a mile from the sea behind a twofold moraine system. Large terminal moraines, stabilized by age and vegetation, are being removed by the sea but remain less disturbed than the outer terminal of the South Glacier. High lateral ridges run into this outer zone. The ice-cored, unstable new moraines within are being abandoned by the thin, flat ice tongues which taper downwards from above the cliff line. As evidence of this, behind these inner moraines, abraded rock surfaces are exposed.

The Swend Foyn Glacier has a steep icefall recessed into the cliff line, but its flat tongue projects beyond it to the shore. A beach was exposed below its $5^{\circ} \mathrm{ft}$. ( $(15 \mathrm{~m}$.) ice cliffs at most stages of the tide, yet calving was in active process. The lateral inoraines were of the young type and related to the present state of the ice. This glacier appeared far more active and cleaner than any of the east coast ones.

The Kjerulf Glacier is larger and equally active. Its icefall is set back more than $\frac{1}{2}$ mile $(0.8 \mathrm{~km}$.) from the cliff line but the tongue projects in front of it further than in the case of the Swend Foyn. It has no old moraine but wide young ones, lower than the crestline of the middle of the glacier. The overhanging and regularly calving ice cliffs are high and project further into the sea than in 
any other case apart from the Weyprecht Glacier. There is no passage along the beach seaward of them.

These last two glaciers have several features in common. They are more convex in crosssection than any described so far and have only one moraine system. There is no sign of any recent lowering of ice level where their valleys intersect the cliffs. Most of the rock cliffs on or near the

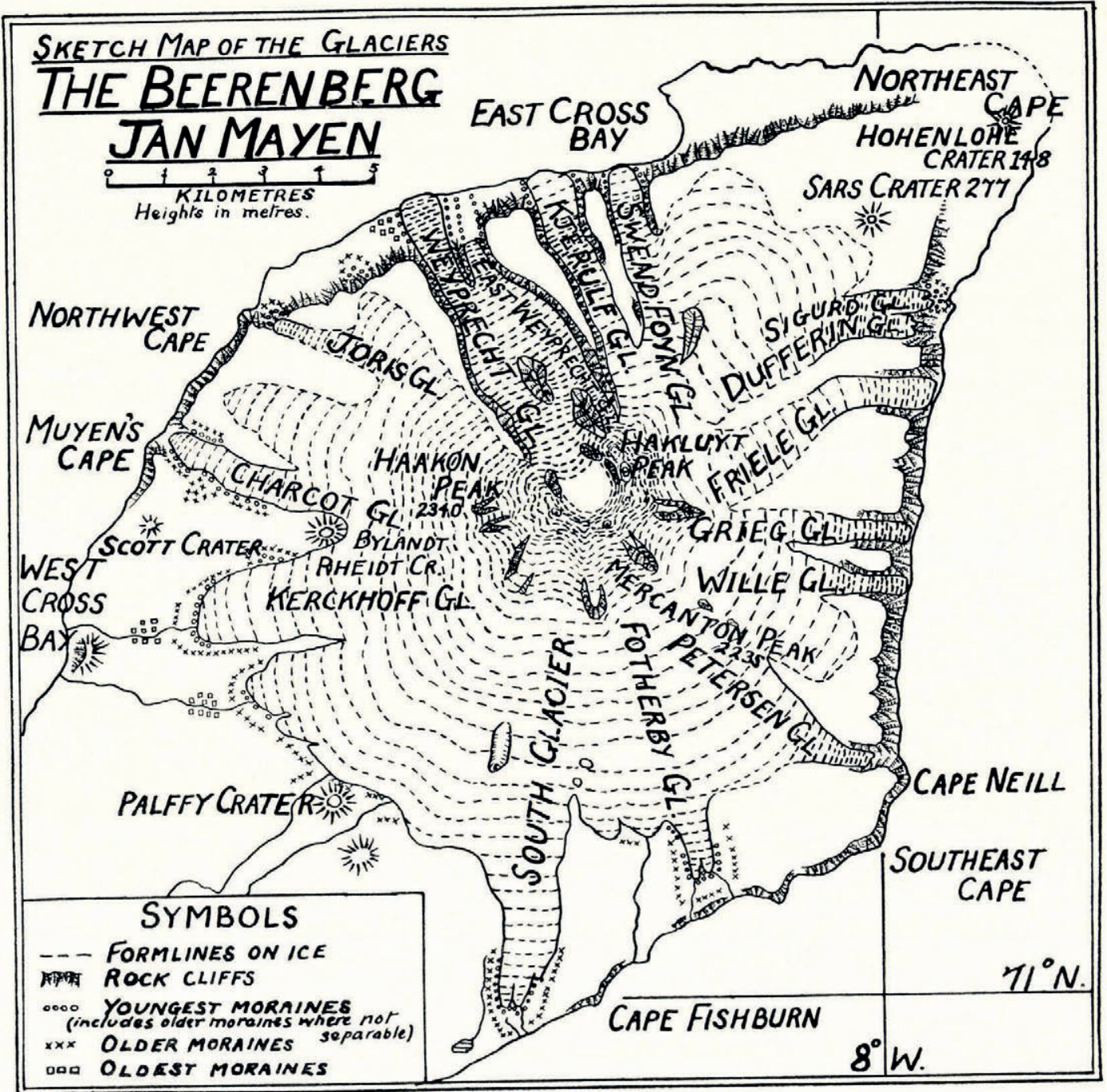

Fig. I. The Glaciers of fan Mayen

coast are covered in parts by a luxuriant type of clinging vegetation due to fertilization by the teeming bird life. The dominant species are the vascular plants, Cochlearia officinalis and Saxifraga rivularis. ${ }^{7}$ The fact that the vegetation on these valley walls grows down to the ice level testifies against any very recent fall in that level. 


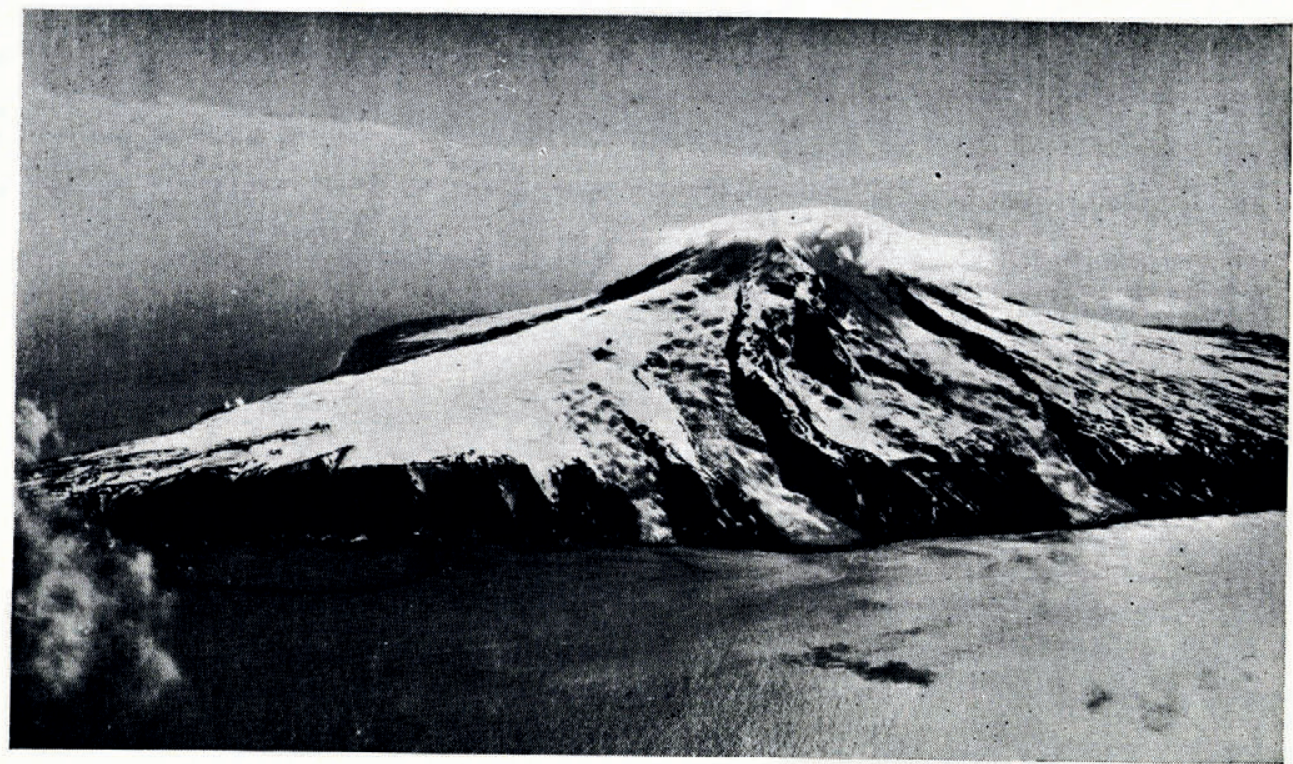

The Beerenberg from the north. The Swend Foyn, Kjerulf and Weyprecht Glaciers can be seen

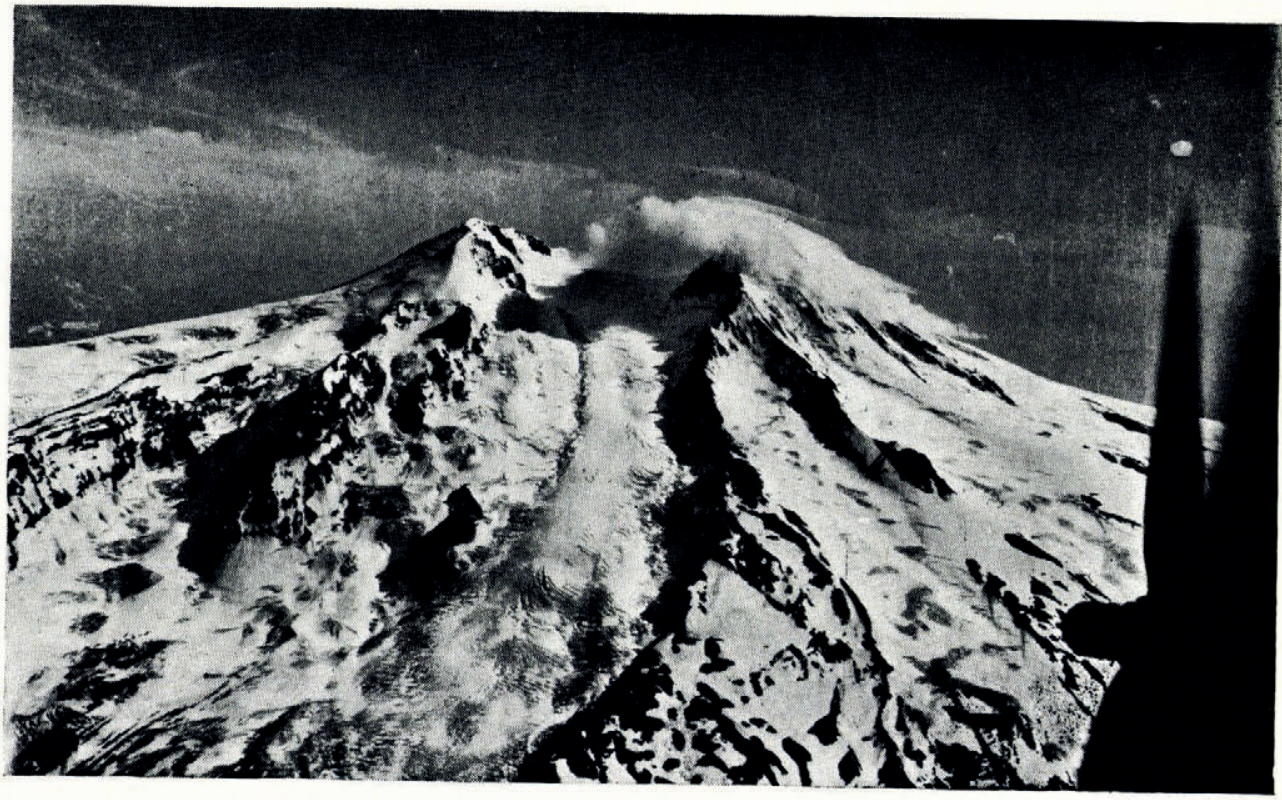

The upper part of the Beerenberg from the north-west showing the Weyprecht Glacier flowing from the crater. Haakon Peak is in cloud.

Air Ministry Photographs Crown Copyright Reserved 
(Continued from p. 170)

The East Weyprecht Glacier presents a distinct contrast to its neighbours, the Kjerulf and the Weyprecht proper. It ends well behind the cliff line in an icefall, heavily encumbered with moraine. In the unoccupied part of the valley below, smoothed and unvegetated slopes stretch up the sidewalls some 200 to $300 \mathrm{ft}$. (6r to $9 \mathrm{I} \mathrm{m}$.) above the debris on its floor. Lateral moraines run to the sea and enclose a central hollow in which are isolated masses of rotting ice. The moraine is unvegetated and loose.

The Weyprecht Glacier is similar to the Friele in that, in its lower parts, two distinct sections are seen. The eastern part looks dead. There are extensive rock outcrops in the glacier bed here behind the cliff line. Seawards of this the ice is heavily covered with moraine and seems almost stationary. The broader, western part is a complete contrast. It extends further into the sea than any glacier in the island, the ice cliffs are the highest and are washed by the sea at all states of the tide. While it was under our observation calving was persistent. In cross-section it is conspicuously convex; it appeared to be in fairly rapid movement since an intermittent booming and cracking was heard when it was crossed. The steepest icefall on the Weyprecht lies well inland of the mountain cliff line but a steep gradient is maintained right to the ice cliffs. West of the Weyprecht there is a considerable area of stable, old moraine outside the present lateral moraine. Aligned hollows preserve the trend of former crevasse lines and show that the Weyprecht formerly splayed out sideways beyond the cliff line. Even so it is still by far the most active glacier in Jan Mayen.

Nearly a mile west of the Weyprecht, moraines on the coastal flat below the cliffs tell of the former presence of a glacier. The ice can be seen reaching but not descending the cliffs. The rock slopes between the ice and the moraines are smoothed and cleaned.

The foris Glacier. The moraines of the Joris Glacier rise very steeply from the coast immediately north of Cape North West. Stable moraine forms an outer fringe enclosing fresh moraine and isolated masses of ice. There are large gaps in the icefall behind, revealing the usual glacier pavement. It was interesting to note that the weaker tuffs were plucked to the extent of forming shallow caves.

The Charcot Glacier. The snout lies $200 \mathrm{yd}$. ( $183 \mathrm{~m}$.) from the shore and consists of an ice cliff up to $30 \mathrm{ft}$. $(9 \mathrm{~m}$.) high. This cliff, not in any way due to wave action, indicates a more active state than is the case with such glaciers as the South and Fotherby. For a short way inland it occupies a fairly deep valley but fairly deep gullies lie between the ice and the valley sides. Further inland, two sets of moraines border the glacier and the stable outer ones stand higher above the ice than in the case of the South Glacier-up to $300 \mathrm{ft}$. $(9 \mathrm{I} \mathrm{m}$.) in places. There is now no branch glacier nearly reaching the sea to the south of Muyen's Cape as shown on the Austrian map of $1882-3$ but an irregular mass of old moraine bulges westwards from the present glacier and corresponds fairly well in position with the site of the active glacier in $1882-3$.

The Kerckhoff Glacier is similar in many respects to the South Glacier, possessing as it does rampart-like laterals with recent low moraines within. The outer laterals stand above the general ground level, although the glacier occupies a shallow valley in the lavas. When, however, the glacier was of a size corresponding to the outer laterals, the ice surface must have been well above the land on either side, that is to say, it was a wall-sided glacier. The glacier surface is now very flat towards its end and the modern terminal is but a slight one. Six hundred yards $(549 \mathrm{~m}$.) away lies the older terminal, perfectly stable and well colonized by vegetation. It joins the laterals but is cut by one melt-water stream. Besides this twofold moraine system, the Kerckhoff has an additional feature in the form of hummocky moraine mounds in the valley below the outer terminal. They cover quite a large area but are irregular in distribution, being cut up by outwash streams. It is important to note that this area of moraine was carefully described in the Austrian report.

The glacier tongue immediately south of the Kerckhoff Glacier possesses an identical 
succession of features. There is a large mass of exceedingly stable and well vegetated moraine in the valley below the glacier; this was described and also mapped by the Austrians. Separated from this morainic dump on the one side and from the glacier on the other by outwash flats is a terminal moraine ridge of stable character and fairly well colonized by plants. Smoothed and plucked bedrock occurs in front of the tapering ice tongue which has little moraine in contact with it. It has retreated from the older terminal but is too inactive to build afresh.

Eastwards to the South Glacier the ice margins betray no signs of movement. Stable ridges of moraine are to be found in front of the ice, which has retreated but built no new moraines. In the valleys west of Palffy Crater moraine ridges are elongated along it and roches moutonnées are exposed on its western flanks. There has been ice retreat here also.

\section{Comparison with Previous Conditions}

It is difficult to date the changes in the ice margin noted above. The accounts of C. Vogt and H. Mohn offer insufficient detail for comparison. Only the Austrian Polar Year Expedition map and the geographical description of Lt. Bóbrik von Boldva, which it accompanies ${ }^{3}$, can be used.

Ward's map shows that the South Glacier does not extend so close to the sea as in the First Polar Year. Von Boldva states that the ice disappeared beneath a terminal moraine no more than $80 \mathrm{~m}$. from the shore. To-day the corresponding figure would be of the order of $800 \mathrm{~m}$., while even the outer margin of the present terminal moraine is $25^{\circ} \mathrm{yd}$. $(230 \mathrm{~m}$.) from the shore at its nearest point. Thus a horizontal retreat of the order of $780 \mathrm{yd} .(7 \mathrm{r} 3 \mathrm{~m}$.) is implied. Substantial marine erosion renders difficult a comparison between conditions in 1882 and 1938 . It is important to note that von Boldva describes the lateral moraines as standing $30 \mathrm{~m}$. above the ice surface. Thus the greater part of the decrease in thickness in the glacier, implicit in the height of the outer laterals, had occurred before the visit of the Austrians.

No plane table survey was made of the ice margin north-westwards to the Kerckhoff Glacier. However, compass resections showed that some of the retreat had occurred since i 882 . In particular the small ice tongue shown extending to the south-west of Palffy Crater no longer exists although it has left its traces. The outer terminal ridges of the Kerckhoff Glacier and the glacier tongue to the south most probably mark the limit of the ice in 1882 . A retreat of several hundred yards must have occurred since then. On the other hand, the areas of hummocky moraine lying outside these terminal ridges, belong to an earlier phase since they were mapped by the Austrians.

North of the Kerckhoff Glacier and east of the South Glacier the Austrian map is so generally inaccurate that it would be unsound to press comparisons too far. One point may, nevertheless, be regarded as definite: if a glacier is mapped as reaching the sea, it is reasonable to accept this as correct even where the coast itself is incorrectly placed. On these grounds retreat since 1882 may be inferred for the Petersen and Dufferin Glaciers, since they do not now reach the sea as the Austrians describe but end high up in the cliffs. Less definite is the case of the Joris Glacier. Von Boldva mentions icebergs on the shore near this glacier; it is certainly impossible for it to supply such to-day. On the other hand, von Boldva's description does not entirely rule out the possibility of those he describes being stranded bergs, perhaps calved from the Weyprecht. Retreat since 1882 is implied by the virtual disappearance of the diffluent southern arm of the Charcot Glacier.

The Fotherby Glacier is anomalous in that here alone does the present ice margin lie beyond that shown by the Austrians. There is not the slightest indication of this glacier on their map nor any mention in von Boldva's description, but it is more reasonable to explain this discrepancy by omission on the part of the Austrians than by an advance of the glacier. The relief is such that the lower part of the Fotherby Glacier is not visible from the sea and much of the Austrian survey was done from boats. The physiographical features, similar to those of the South Glacier, point most definitely to the retreat general in the island.

I3 
It is of interest to note here that the sea ice does not surround and stay in the neighbourhood of Jan Mayen as long as formerly. The First Polar Year was exceptional, the pack ice did not leave the island till 26 July 1882 . By contrast, in the summer of 1938 , one patch of pack ice, seen in the sea to the west from the summit of Hakluyt Peak of the Beerenberg, was all we could record. The Danish Meteorological Service's reports on the ice conditions in the Arctic make it clear that since 1913 the pack ice has only rarely advanced as far east as the average position for the period 18981913. Th. Iversen ${ }^{8}$ tabulates the sea temperatures taken in 1877,1900 and 1930 at roughly the same place in Great Wood Bay and at the same time of the year. A rise in temperature is recorded which may be correlated with the improving ice conditions.

Position $-70^{\circ} 5^{\prime}$ N., $8^{\circ} 22^{\prime} \mathrm{W}$.

Date

Surface temperature

$$
\text { I August } 1877
$$

$3 \cdot 5^{\circ} \mathrm{C}$.
8 August 1900 $4.20^{\circ} \mathrm{C}$.

\section{August $193^{\circ}$ $7.07^{\circ} \mathrm{C}$.}

Iversen also discusses the meteorological conditions recorded by the Austrians in $1882-83$ and finds both summer and winter temperatures lower than the averages for $1921-33$ from the Norwegian Meteorological Station at Jameson Bay. But as the Austrian Station was 4 miles away at the other side of the island, this comparison must be accepted with caution.

\section{Relative Activity of the Glaciers}

The different degrees of activity displayed by the glaciers of such a small island as Jan Mayen with its simple relief are instructive. In 1938 the Weyprecht, Kjerulf and Swend Foyn Glaciers were by far the most active and in that order. In 1882 they were also the most active. The Austrians found that the South Glacier near its snout did not move measurably in 243 days, whereas the Weyprecht moved $3 \mathrm{~m}$. in a 24 -hour period and $2.34 \mathrm{~m}$. in a separate 23 -hour period. The Kjerulf averaged $0.19 \mathrm{~m}$. per 24 hours over three days, but here the point utilized was near the side of the glacier and the middle moved appreciably faster.

Not all the northerly facing glaciers were active in 1938 ; the East Weyprecht was in strong retreat and inactive. This may be related to differences in the accumulation areas. The main stream of the Weyprecht might be expected to be the most active, since it drains the crater basin of the Beerenberg, by far the largest accumulation area at the high levels. On the other hand, the East Weyprecht and that part of the Weyprecht which has a moribund appearance, do not derive ice from the crater basin but drain the very limited outer slopes of the upper cone of the Beerenberg. The Kjerulf and the Swend Foyn have a common névé field in a much more extensive area of the northward-facing slopes of the upper cone. Since the East Weyprecht depends much more on the lower levels for its alimentation than its neighbours, any rise in the firn line would affect it more, and this might be registered in the retreat of the snout as was observed. In general the northward facing slopes of the Beerenberg and the crater itself appear to form much more favourable névé fields than the other slopes. The summer of 1938 saw the firn line rise to more than $3000 \mathrm{ft}$. (914 m.) on the southern side, whereas on the northern side it lay between $2000(610 \mathrm{~m}$.) and $2250 \mathrm{ft}$. $(636 \mathrm{~m}$.), a figure more in agreement with V. Paschinger's figure for the beginning of the century. ${ }^{9}$

\section{CONCLUSIONS}

The geomorphological features of the ice margin demonstrate that the glaciers have been retreating for some time. From examination of the different types of moraine it seems that the retreat has two phases. The first is characterized by extensive areas of hummocky moraine found outside the Kerckhoff Glacier and its neighbour to the south. The moraines on the western side of the foot of the Weyprecht Glacier probably belong to this earlier phase also. The massiveness of the deposits implies a slow retreat of the snouts, while moraine was still being actively brought 
down. This occurred before the visit of the Austrian expedition. The second phase of the retreat is represented by the twofold sets of terminal and lateral moraine ridges described for the Kerckhoff, South, Fotherby and other glaciers. This retreat must have been fairly rapid and the glaciers inactive, since there was little or no accumulation of moraine between the outer and inner ridges. This retreat, then, belongs mainly, if not entirely, to the period since $1882-83$, but vertical thinning must have been going on before then.

$\mathrm{S}$. Thorarinsson ${ }^{2}$ has compared these features with the better known glacier variations in Iceland and Norway and attributes the second phase of retreat to the period after the Hochstand in the middle or latter half of the nineteenth century. With less certainty he relates the outermost moraines to an advance in the middle of the eighteenth century.

In 1938 some of the northerly flowing glaciers were more active than the others and have not retreated to the same extent, but in general the glaciers were still in retreat. Notably the Joris and Sigurd Glaciers were receding from their innermost moraines.

\section{ACKNOWLEDGMENTS}

The 1938 Expedition was made possible by grants from the Leverhulme Research Foundation and the Central Research Fund of the University of London. I wish here to express my thanks for a personal grant from St. Catharine's College, Cambridge. Mr. W. V. Lewis has assisted me valuably with the manuscript, ard I am indebted to him. The photographs have been supplied through the courtesy of Fl.-Lt. S. Banks, R.A.F.

Following the current edition of Admiralty Chart 2715 and the map of the Imperial College Expedition published in the Geographical fournal, Vol. 94, No. 2, 1939, the place-names in this paper have been given in English form. In accordance with the practice recommended by the Permanent Committee on Geographical Names these names will appear in Norwegian form in future Admiralty publications. The following list gives the equivalent English and Norwegian forms:

\section{English Form}

Beerenberg

Byland Rheidt Crater

Cape Fishburn

Cape Hope

Charcot Glacier

Clandeboy Cove

Dufferin Glacier

East Cross Bay

East Weyprecht Glacier

Fotherby Glacier

Friele Glacier

Great Wood Bay

Greig Glacier

Haakon Peak

Hakluyt Peak
Norwegian Form

Beerenburg

Bylandt Rheidtkrateret

Kapp Fishburn

Kapp Håp

Charcotbreen

Clandeboybukta

Dufferinbreen

Austre Krossbukta

Austre Weyprechtbreen

Fotherbybreen

Frielebreen

Rekvedbukta

Griegbreen

Haakontoppen

Hakluyttoppen

English Form
ameson Bay
oris Glacier
erckhoff Glacier
jerulf Glacier
Mercanton Peak
Muyen's Cape
orth-west Cape
alffy Crater
Petersen Glacier
ars Crater
gurd Glacier
outh Glacier
wend Foyn Glacier
eyprecht Glacier
ille Glacier

Norwegian Form

Jamesonbukta

Jorisbreen

Kerckhoffbreen

Kjerulf breen

Mercantontoppen

Kapp Muyen

Nordvestkapp

Palffykrateret

Petersenbreen

Sarskrateret

Sigurdbreen

Sørbreen

Svend Foynbreen

Weyprechtbreen

Willebreen

MS. received 18 March 1947

\section{RE F E R E N CES}

I. Jennings, J. N. The Glaciers of Jan Mayen, Appendix II to A. King, The Imperial College of Science Expedition to Jan Mayen Island. Geog. Fourn., Vol. 94, No. 2, 1939, p. 128-31.

2. Thorarinsson, S. Present Glacier Shrinkage and Eustatic Changes of Sea Level. Geografiska Annaler, Årg. 22, Häft $3-4,1940$, p. $131-59$

3. Boldva, Adolf Bóbrik von. Aữnahme und Beschreibung der Insel Jan Mayen. Beobachtungen über Gletscherbewegung. Die Oesterreichische Polarstation Jan Mayen: Beobachtungs-Ergebnisse, Wien, I 886, Bd. I, p. 27-50.

4. Russell, I. C. The Glaciers of Mt. Rainier. I 8th Annual Report of U.S. Geological Survey, Part 2.

5. Reid, H. F. Studies of the Glaciers of Mt. Hood and Mt. Adams. Zeit. für Gletscherkunde, Bd. I, r913.

6. Wordie, J. M. The Geology of Jan Mayen. Trans. Roy. Soc. Edinburgh, Vol. 54, Part 3 (No. 18), 1926, p. $741-45$. of , R. S. and Wellington, P. S. Physiological and Ecological Studies on Arctic Vegetation. I. The Vegetation

8. Iversen. r936.

9. Paschinger, V. Die Schneegrenze in verschiedenen Klimaten. Peterm 1912. 